\title{
Species-specific trajectories of nitrogen isotopes in Indiana hardwood forests, USA
}

\author{
K. K. McLauchlan ${ }^{1}$ and J. M. Craine ${ }^{2}$ \\ ${ }^{1}$ Department of Geography, Kansas State University, Manhattan, KS 66506, USA \\ ${ }^{2}$ Division of Biology, Kansas State University, Manhattan, KS 66506, USA \\ Correspondence to: K. K. McLauchlan (mclauch@ksu.edu)
}

Received: 12 April 2011 - Published in Biogeosciences Discuss.: 28 June 2011

Revised: 24 January 2012 - Accepted: 6 February 2012 - Published: 24 February 2012

\begin{abstract}
Humans have drastically altered the global nitrogen $(\mathrm{N})$ cycle, and these alterations have begun to affect a variety of ecosystems. In North America, $\mathrm{N}$ deposition rates are highest in the central US, yet there are few studies that examine whether $\mathrm{N}$ availability has been increasing to different tree species in the forests of the region. To determine the species-specific trajectories of $\mathrm{N}$ availability in secondary temperate forests experiencing high $\mathrm{N}$ deposition, we measured the $\mathrm{N}$ concentrations and composition of stable $\mathrm{N}$ isotopes in wood of four tree species from six hardwood forest remnants in northern Indiana, USA. Annual nitrogen deposition rates averaged $5.8 \mathrm{~kg} \mathrm{ha}^{-1}$ from 2000 to 2008 in this region. On average, wood $\delta^{15} \mathrm{~N}$ values in Quercus alba have been increasing steadily over the past 100 years. In contrast, wood $\delta^{15} \mathrm{~N}$ values have been declining in three other hardwood species - Acer saccharum, Carya ovata, and Fagus grandifolia-over the same time period. The species-specific trends suggest a change in the partitioning of ammonium and nitrate among species, due to an increase in nitrification rates over time. With no apparent net change in wood $\delta^{15} \mathrm{~N}$ over the past century at the stand level, there is currently little evidence for consistent trends in stand-level $\mathrm{N}$ availability over time in the Indiana forests.
\end{abstract}

\section{Introduction}

Modern temperate forests are experiencing an unprecedented variety of anthropogenic changes on a global scale, such as increasing levels of atmospheric $\mathrm{CO}_{2}$, increased temperature, and increased deposition of reactive forms of nitrogen $(\mathrm{N})$ from the atmosphere (Kareiva et al., 2007). In addition to these regional- to global-scale changes, many forests are ex- periencing local changes in fire regimes, drought, and the introduction of non-native plants and animals while recovering from earlier logging and windthrow. Not only do many of these factors have the potential to interact in their effects on forest processes, but they also have the potential to enhance or dampen $\mathrm{N}$ availability, which often limits primary productivity and influences forest species composition (Pepper et al., 2007). For example, experiments have suggested that elevated $\mathrm{CO}_{2}$ may decrease terrestrial $\mathrm{N}$ availability (Johnson, 2006; Luo et al., 2004), while chronic $\mathrm{N}$ deposition may increase $\mathrm{N}$ availability to temperate forests (Aber et al., 2003).

Although understanding how global change factors affect the $\mathrm{N}$ cycle is of paramount importance to predicting forest dynamics, long-term records of $\mathrm{N}$ cycling in forests are rare and generally restricted to modern measurements that might span a few decades at most (Stoddard et al., 1999; Bernhardt et al., 2005). A more temporally-complete understanding of the modern trajectory of $\mathrm{N}$ cycling in forests requires extending records back in time beyond the modern record (Galloway et al., 2004). Analysis of the natural abundance ratios of ${ }^{15} \mathrm{~N}$ to ${ }^{14} \mathrm{~N}$ in wood of living trees can serve as a proxy record for the history of $\mathrm{N}$ cycling in terrestrial ecosystems (Bukata and Kyser, 2005, 2007; McLauchlan et al., 2007; Savard et al., 2009; Hietz et al., 2010). Although the $\mathrm{N}$ cycle is complex and the lack of direct climate information contained in $\mathrm{N}$ isotopes has previously hindered their use (McCarroll and Loader, 2004), recent analytical and conceptual advances suggest that $\mathrm{N}$ isotopic signatures in terrestrial ecosystems can be reliably interpreted (Savard, 2010; Houlton and Bai, 2009). Consensus is emerging that the standardized ratio of ${ }^{15} \mathrm{~N}$ to ${ }^{14} \mathrm{~N}\left(\delta^{15} \mathrm{~N}\right)$ in soil and leaves integrates a complicated terrestrial $\mathrm{N}$ cycle into a single metric that reflects terrestrial $\mathrm{N}$ availability (Craine et 
al., 2009). Briefly, there are a few major processes that alter the $\delta^{15} \mathrm{~N}$ signature in plant material as compounds containing ${ }^{15} \mathrm{~N}$ are discriminated against in key steps of the $\mathrm{N}$ cycle (Högberg, 1997). The steps that fractionate most strongly are gaseous loss pathways, especially denitrification (Groffman et al., 2006; Menyailo and Hungate, 2006), gaseous loss during nitrification, and ammonia volatilization at high soil $\mathrm{pH}$, and the transfer of $\mathrm{N}$ from mycorrhizal fungi to plants (Handley and Raven, 1992;Bedard-Haughn et al., 2003). Although there are many processes that discriminate against ${ }^{15} \mathrm{~N}$, stand-level plant $\delta^{15} \mathrm{~N}$ generally increases with increasing $\mathrm{N}$ availability, here defined as the supply of $\mathrm{N}$ to terrestrial plants and soil microorganisms relative to their $\mathrm{N}$ demands (Schimel and Bennett, 2004). In forests, high $\delta^{15} \mathrm{~N}$ values are found in soils and leaves of ecosystems with high rates of nitrification (Pardo et al., 2006), high rates of denitrification (Houlton et al., 2006), partial nitrification followed by nitrate leaching (Pardo et al., 2002), and low reliance on mycorrhizal fungi for plant $\mathrm{N}$ uptake (Hobbie and Colpaert, 2003; Högberg et al., 2011).

Wood in living trees provides a widespread and readilyavailable record of $\mathrm{N}$ isotopes associated with terrestrial ecosystems that can be used to reconstruct terrestrial $\mathrm{N}$ cycling. Wood has very low $\mathrm{N}$ concentrations, and most of the $\mathrm{N}$ in wood is located in proteins complexed with cellulose in cell walls (Bao et al., 1992; Showalter, 1993). N isotopes in wood have recorded clearance events in Ontario (Bukata and Kyser, 2005) and New Hampshire (McLauchlan et al., 2007), regional pollution in eastern Canada (Bukata and Kyser, 2007; Savard et al., 2009) and Switzerland (Saurer et al., 2004), and short-term fertilization experiments in California (Hart and Classen, 2003), France (Elhani et al., 2005), and Scotland (Guerrieri et al., 2011). Ultimately, the analysis of natural abundance nitrogen isotopes in wood has the potential to elucidate whether forests are generally experiencing increased or decreased $\mathrm{N}$ availability.

In North America, some of the highest rates of $\mathrm{N}$ deposition occur in the Midwest region due to extensive inorganic fertilizer application to agricultural fields that began in the 1940s. The forests of this region are the most likely in North America to be experiencing eutrophication, but it is unknown how widespread this pattern might be or if all tree species in a forest respond similarly to the effects of $\mathrm{N}$ deposition. To better understand the changes in $\mathrm{N}$ cycling in temperate forests of the region, we obtained records of $\mathrm{N}$ isotopes, $\mathrm{N}$ concentrations, and ring widths from four tree species in six forest remnants in northwestern Indiana. We expected to see an increase in wood $\delta^{15} \mathrm{~N}$ in all hardwood tree species beginning in the mid-20th century. Alternatively, stand-level declines in wood $\delta^{15} \mathrm{~N}$ would likely signal declines in $\mathrm{N}$ availability, while the lack of significant changes would indicate that $\mathrm{N}$ availability was not changing. We also analyzed the dendroisotopic records separately for each species, to assess whether there are species-specific trajectories of $\mathrm{N}$ isotopes that might signal changes in $\mathrm{N}$ cycling.

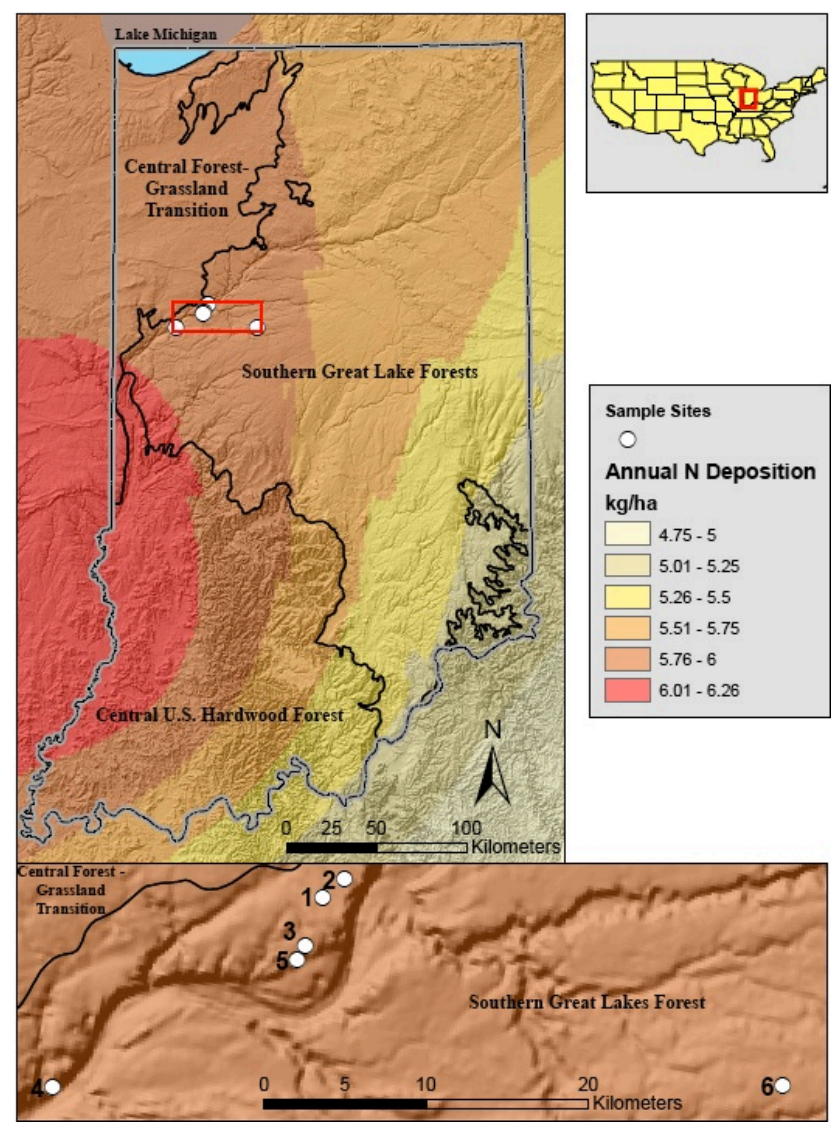

Fig. 1. Locations of six study sites in Indiana, with interpolated $\mathrm{N}$ deposition from the National Atmospheric Deposition Program, ecoregions delineated by the World Wildlife Fund, and topography from the United States Geological Survey. On the lower panel, 1 is Cumberland Woods, 2 is Rosebank Woods, 3 is McCormick Woods, 4 is Black Rock Barrens, 5 is Purdue Arboretum, and 6 is Bryan Woods.

\section{Methods}

\subsection{Study site}

Increment cores were collected from six forest remnants in northwest Indiana (Fig. 1). All sites are within $50 \mathrm{~km}$ of one another, in the southern Great Lakes forests ecoregion which is characterized by Alfisols (Olson et al., 2001). Extensive hardwood forests dominated by Quercus alba were common in the region prior to Euro-American settlement (Cowell and Hayes, 2007). These forests were cleared rapidly and converted to agricultural fields during the mid-19th century, and today the region is known as the Corn Belt, dominated by industrial agriculture. Each forest remnant contained a mix of species, generally with oaks (Quercus spp.) at all sites, shagbark hickory (Carya ovata) abundant in the drier sites, and sugar maple (Acer saccharum) and/or beech (Fagus grandifolia) abundant in the more mesic sites. At each site, a single large individual Quercus alba tree was chosen near the center 
of the forest remnant, and it and the nearest two trees were sampled. Trees were no farther than $20 \mathrm{~m}$ apart at each site. This sampling design focuses on temporal change in the $\mathrm{N}$ cycle while keeping other state factors as constant as possible.

$\mathrm{N}$ deposition in this area is among the highest in the US. The average amount of inorganic $\mathrm{N}$ deposited each year at these locations was $5.8 \mathrm{~kg} \mathrm{ha}^{-1}$ from 2000 to 2008 (National Atmospheric Deposition Program; http://nadp.sws. uiuc.edu). The source of this deposition is primarily inorganic $\mathrm{N}$ fertilizer applied to intensive corn and soybean agriculture in the region.

\subsection{Increment cores: sampling, dating, and mass spectrometry.}

Sampling consisted of a $5.15 \mathrm{~mm}$ diameter increment core that spanned the entire radius of each tree acquired $1 \mathrm{~m}$ above the forest floor. Replication focused on the region, so three individual living trees were sampled at each site, generally Quercus alba, Carya ovata, Acer saccharum, or Fagus grandifolia (hereafter referred to by genus only). Trees of different ages allowed us to test for temporal effects independent of tree age (Hietz et al., 2010). Each increment core was stored in a paper straw and dried at $60^{\circ} \mathrm{C}$ until no further mass loss was observed. The face of each increment core was sanded to increase the contrast between rings and then scanned at $1200 \mathrm{dpi}$. Each image was analyzed for ring width with Cybis CDendro software (Saltsjöbaden, Sweden). The heartwood-sapwood boundary was determined visually on all but one increment core. An age was assigned to each ring after cross-dating. Each core was weighed and divided into $30 \mathrm{mg}$ segments along ring boundaries, providing enough $\mathrm{N}$ for mass spectrometry while maximizing the temporal resolution of the record and limiting the carbon content and risk of incomplete combustion. The wood samples were not subjected to any chemical pretreatments based on results from (Bukata and Kyser, 2005; Hietz et al., 2010; Doucet et al., 2011). The standardized ratio of ${ }^{15} \mathrm{~N}:{ }^{14} \mathrm{~N}$ relative to air $\left(\delta^{15} \mathrm{~N}\right)$ was determined for segments of wood at the Stable Isotope Mass Spectrometry Laboratory at Kansas State University on a ThermoFinnigan Delta Plus mass spectrometer interfaced with a Carlo Erba 1110 elemental analyzer with Conflo II interface (Thermo Fisher Scientific Inc., Waltham, MA, USA), fitted with sequential traps of $\mathrm{MgClO}_{4}, \mathrm{NaOH}$ on solid support (Carbosorb), and a cold trap in liquid $\mathrm{N}_{2}$. Generally, every third segment of wood was analyzed resulting in an average length of time represented by a segment of 4.5 years with 426 segments analyzed.

\subsection{Statistical methods}

The data from the increment cores $\left(\operatorname{wood} \delta^{15} \mathrm{~N}, \mathrm{~N}\right.$ concentration, and ring width) were manipulated as little as possible to reveal trends that might be obscured with detrending or sta-

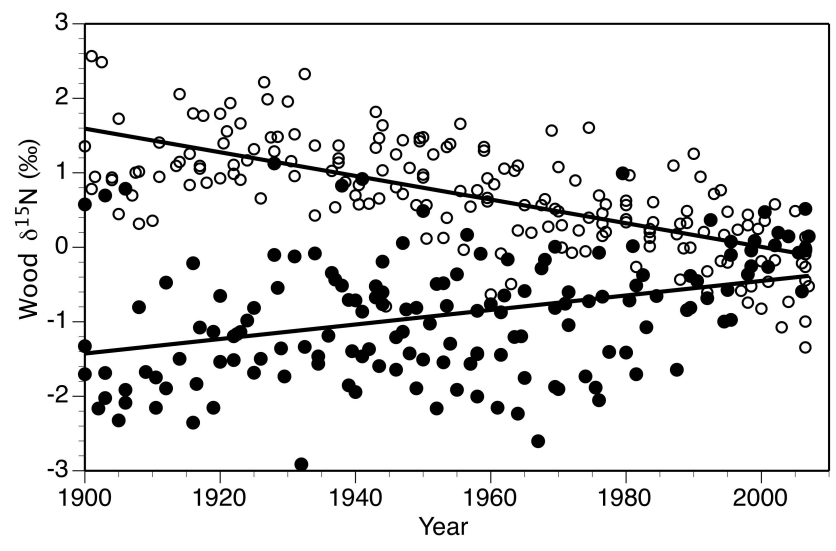

Fig. 2. Wood $\delta^{15} \mathrm{~N}$ over time standardized to the same mean $(0 \%$ o $)$ across sites for Quercus alba (solid circles) and three other hardwood species (Carya ovata, Fagus grandifolia, and Acer saccharum, open circles). Lines represent linear regression between mean year of wood formation for each segment and wood $\delta^{15} \mathrm{~N}$ values for Quercus alba $\left(r^{2}=0.11, P<0.001\right)$ and other species $\left(r^{2}=0.46\right.$, $P<0.001)$.

tistical treatments that are applied temporally (Gavin et al., 2008). Average wood $\delta^{15} \mathrm{~N}$ was standardized to the same mean value for each site, centered around $0 \%$. ANOVA revealed that $\delta^{15} \mathrm{~N}$ values for Quercus wood were significantly lower than the other three species $(P<0.001$; Tukey's HSD) and so patterns for Quercus were analyzed separately. Differences in the trajectories of $\delta^{15} \mathrm{~N}$ over time for the two species sets were compared with mutliple regression. Wood $\mathrm{N}$ concentrations and $\delta^{15} \mathrm{~N}$ for each increment core were analyzed with simple linear regression against age for all wood with dates after 1900 C.E., which helped account for different ages among individual trees and species and to facilitate comparisons among sites.

\section{Results and discussion}

\subsection{Long-term records of stable $\mathbf{N}$ isotopes.}

On average, values of wood $\delta^{15} \mathrm{~N}$ for Quercus were $1.85 \%$ lower than the other three species ($1.52 \%$ vs. $0.33 \%$ o $P<0.001)$ with no significant differences in average wood $\delta^{15} \mathrm{~N}$ values among the other three species $(P=0.77)$. Standardizing wood $\delta^{15} \mathrm{~N}$ among sites produced similar differences between the two species groups: Quercus wood $\delta^{15} \mathrm{~N}$ values were $1.73 \%$ o lower than those in the other hardwood species.

Temporal trends in wood $\delta^{15} \mathrm{~N}$ differed among the four hardwood species examined (Fig. 2). After standardizing wood $\delta^{15} \mathrm{~N}$ so that all the sites had the same mean $\delta^{15} \mathrm{~N}(0 \%$ o from 1900-2008, Quercus wood $\delta^{15} \mathrm{~N}$ increased over time at a rate of $0.009 \% \mathrm{yr}^{-1}$. In contrast, wood $\delta^{15} \mathrm{~N}$ for the other three species-Carya, Fagus, and Acer-declined at a rate of 


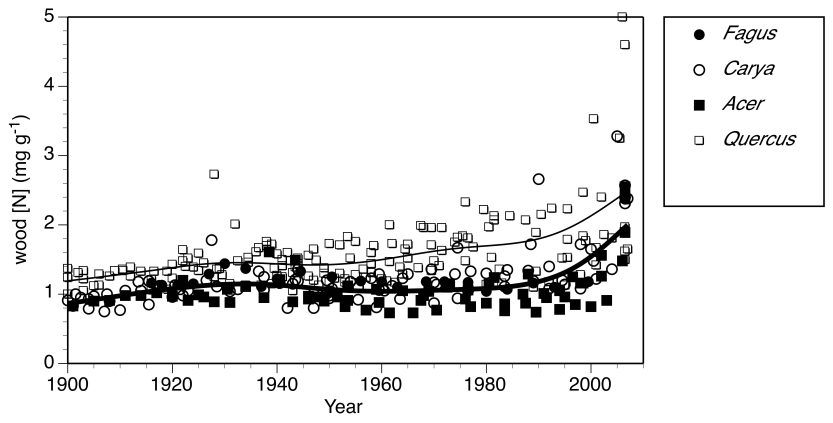

Fig. 3. Wood [N] over time. The thin line is a spline fit for Quercus wood, while the thick line is a spline fit for the three other hardwood species.

$0.016 \% \mathrm{yr}^{-1}$. Analyzing the linear rates of change over the entire period of analysis, there was no significant difference among the three species in their trends $(P=0.78)$ (Fig. 2, Table 1). Thus, there are contrasting trends where Quercus wood $\delta^{15} \mathrm{~N}$ has increased over time while wood $\delta^{15} \mathrm{~N}$ for other hardwoods has decreased.

\subsection{Wood N concentration}

All species had higher $\mathrm{N}$ concentrations in wood formed after 2000 C.E., which was sapwood. Before 2000, N concentrations increased over time for both sets of species $(P<0.01$ for both), but $\mathrm{N}$ concentrations increased more for Quercus $\left(0.0056 \mathrm{mg} \mathrm{g}^{-1} \mathrm{yr}^{-1}\right)$ than for other species $\left(0.0015 \mathrm{mg} \mathrm{g}^{-1} \mathrm{yr}^{-1}\right)(P<0.001)$ (Fig. 3). Sapwood has been shown to have higher $\mathrm{N}$ concentrations than heartwood in several tree species (Merrill and Cowling, 1966), and this pattern is consistent in both untreated wood and wood treated to remove water- and lipid-soluble compounds (Hietz et al., 2010). Thus, the higher $\mathrm{N}$ concentrations in sapwood than heartwood cannot be entirely explained by the higher proportion of labile $\mathrm{N}$-containing compounds in living cells, and future research should help identify under what conditions a chemical extraction procedure might be useful. A recent, comprehensive study by Doucet et al. (2011) found that $\mathrm{N}$ translocation did not generate significant isotopic fractionation across the heartwood-sapwood boundary. One of the tree species in that study was Fagus grandifolia, which we also studied here. Wood $\mathrm{N}$ concentrations and $\delta^{15} \mathrm{~N}$ values for each increment core are shown in Fig. 4. N concentrations are highest in the most recent wood, sometimes far from the heartwood-sapwood boundary (Fig. 4). The position of the heartwood-sapwood boundary varies among individual increment cores.

\subsection{Age of trees and ring-width increments}

Differences in temporal trends in wood $\delta^{15} \mathrm{~N}$ values between the two sets of species were not due to differences in the ages of trees. The oldest wood sampled for all trees ranged from
1855 to 1953 C.E. (Table 1). The oldest wood we sampled for Quercus averaged 1898 C.E. among trees, compared with 1880 C.E. for Carya, 1922 C.E. for Acer, and 1916 C.E. for Fagus. Nor were there marked differences in radial increment trajectories for the two sets of species. On average, since 1900 C.E. the radius of Quercus trees increased by $2.34 \pm 0.04 \mathrm{~mm} \mathrm{yr}^{-1}$, while other species increased at just $1.66 \pm 0.03 \mathrm{~mm} \mathrm{yr}^{-1}$ (Fig. 5). Yet, radial increment for all species declined over time, with Quercus radial increment decreasing at a rate of $0.01 \mathrm{~mm} \mathrm{y}^{-1}$ and other species at $0.005 \mathrm{~mm} \mathrm{yr}^{-1}(P=0.003)$. All six sites exhibit expected trends of reduced radial growth over time.

The demography of nearby old-growth forest stands in Indiana indicates that the composition of tree species will be shifting in the near future, as canopy species such as Quercus spp. are replaced by subcanopy species such as Acer saccharum (Cowell and Hayes, 2007). High mortality in the subcanopy and a limited role of canopy gaps for favoring Quercus spp. may complicate these dynamics, however (Cowell et al., 2010). Our results indicate that altered nutrient dynamics in these forest remnants surrounded by agriculture are not substantially influencing these normal demographic processes.

\subsection{Potential changes in $\mathrm{N}$ cycling}

Quercus wood $\delta^{15} \mathrm{~N}$ consistently increased at all sites over the duration of the record. If this increase were representative of stand-level signatures, it would indicate increasing $\mathrm{N}$ availability, either as a result of enrichment of $\mathrm{N}$ sources to the trees or reduced reliance on mycorrhizal fungi. Yet, the increases in Quercus wood $\delta^{15} \mathrm{~N}$ were accompanied by decreases in wood $\delta^{15} \mathrm{~N}$ of Acer, Fagus, and Carya species from the same stands. The ultimate stand-level changes in $\mathrm{N}$ cycling depend on the relative amounts of $\mathrm{N}$ acquired by the two sets of trees. If they are similar in magnitude and opposite in direction at the stand level, that would indicate that $\mathrm{N}$ availability has not changed since 1900 .

The different trajectories in wood $\delta^{15} \mathrm{~N}$ between Quercus and the other hardwood tree species could be caused by several factors. The most likely is that nitrification has been increasing over time, which decreases partitioning of $\mathrm{N}$ sources among tree species. Nitrification, the conversion of ammonium to nitrate, is a strongly fractionating step that results in isotopic enrichment of $\mathrm{NH}_{4}^{+}$and depletion of $\mathrm{NO}_{3}^{-}$(Högberg 1997). For a given site, plants that rely more on $\mathrm{NH}_{4}^{+}$would be relatively enriched in ${ }^{15} \mathrm{~N}$ and plants that rely more on $\mathrm{NO}_{3}^{-}$would be relatively depleted in ${ }^{15} \mathrm{~N}$. Herbaceous plant species partition sources of $\mathrm{N}$ such that consistent, interpretable differences among species in foliar $\delta^{15} \mathrm{~N}$ are maintained (Kahmen et al., 2008). Over time, this could lead to species-specific trajectories of $\delta^{15} \mathrm{~N}$ in plant tissue, as the type and quantity of $\mathrm{N}$ sources vary. However, there has been little evidence for this effect in wood $\delta^{15} \mathrm{~N}$ to date. When the wood $\delta^{15} \mathrm{~N}$ of two or more species have been studied in 
Table 1. Simple linear regressions between wood $\delta^{15} \mathrm{~N}$ and year of wood formation for eighteen trees sampled in Indiana, USA. The slope is since 1900. Tree diameter (diam) is based on the length of increment core. First year is the earliest date for wood analyzed, not the pith date or year established.

\begin{tabular}{llrrrrr}
\hline Site & Species & $\begin{array}{r}\text { First Year } \\
\text { (C.E.) }\end{array}$ & $\begin{array}{r}\text { Diam } \\
(\mathrm{cm})\end{array}$ & $r^{2}$ & $\mathrm{~m}$ & $P$ \\
\hline \multirow{2}{*}{ Black Rock Barrens } & Carya ovata & 1943 & 26 & 0.91 & -0.038 & $<0.001 *$ \\
& Quercus alba & 1920 & 45 & 0.00 & 0.001 & 0.83 \\
& Quercus alba & 1938 & 22 & 0.33 & -0.013 & $0.03 *$ \\
Bryan Woods & Carya ovata & 1872 & 44 & 0.37 & -0.014 & $0.002^{*}$ \\
& Acer saccharum & 1948 & 30 & 0.71 & -0.027 & $<0.001 *$ \\
& Quercus alba & 1855 & 74 & 0.16 & 0.010 & $0.05^{*}$ \\
Cumberland Woods & Carya ovata & 1861 & 45 & 0.29 & -0.011 & $0.05^{*}$ \\
& Acer saccharum & 1938 & 55 & 0.69 & -0.017 & $<0.001 *$ \\
McCormick Woods & Quercus alba & 1881 & 19 & 0.01 & 0.002 & 0.68 \\
& Carya ovata & 1872 & 80 & 0.61 & -0.008 & $<0.001 *$ \\
& Acer saccharum & 1893 & 33 & 0.65 & -0.017 & $<0.001 *$ \\
Purdue Arboretum & Quercus alba & 1893 & 42 & 0.36 & 0.013 & $0.001 *$ \\
& Fagus grandifolia & 1916 & 44 & 0.30 & -0.015 & $0.01 *$ \\
& Acer saccharum & 1922 & 46 & 0.55 & -0.011 & $<0.001 *$ \\
Rosebank Woodlot & Quercus alba & 1939 & 46 & 0.55 & 0.028 & $<0.001 *$ \\
& Carya ovata & 1856 & 74 & 0.66 & -0.018 & $<0.001 *$ \\
& Quercus alba & 1863 & 37 & 0.62 & 0.019 & $<0.001 *$ \\
& Acer saccharum & 1953 & 33 & 0.62 & -0.039 & $<0.001 *$ \\
\hline
\end{tabular}
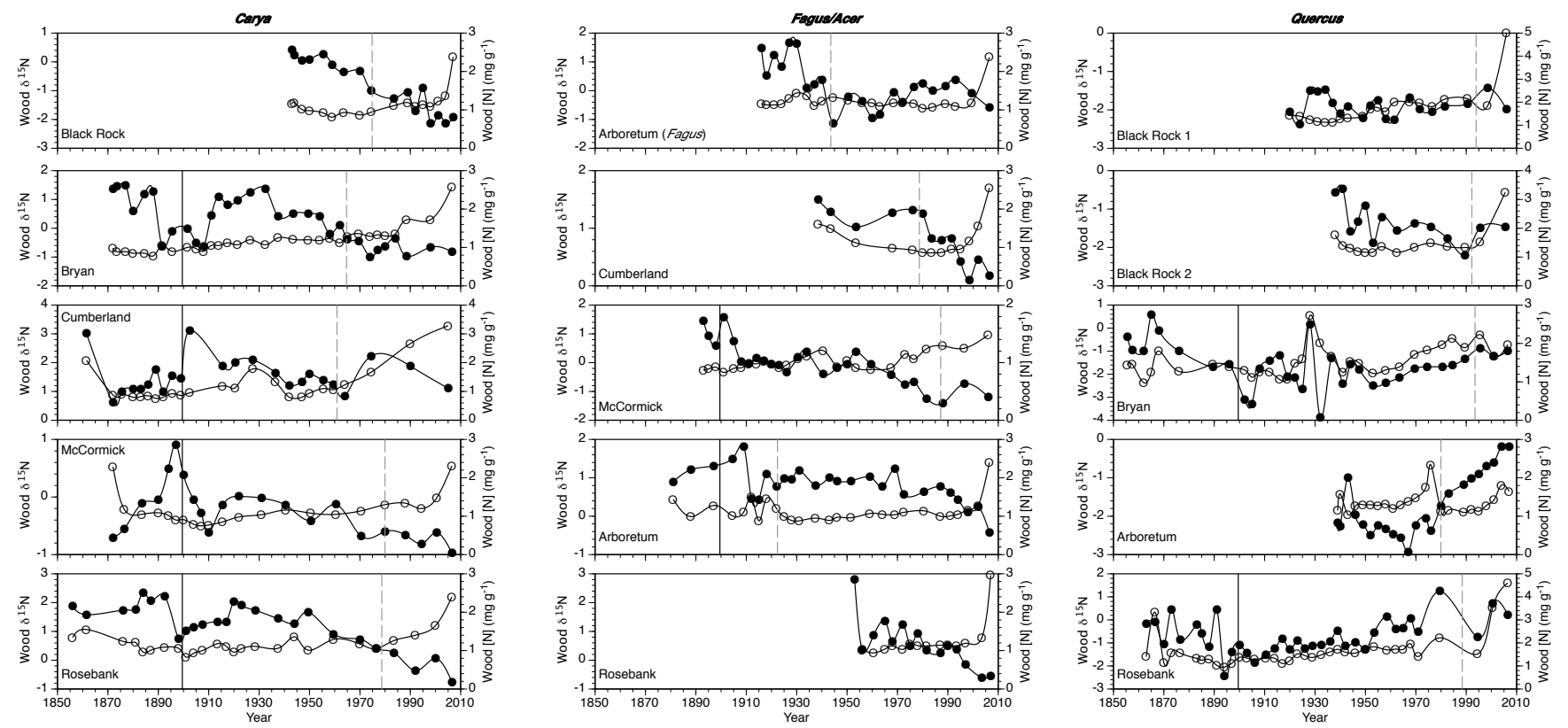

Fig. 4. Nitrogen characteristics of wood samples from each individual tree sampled. For each increment core, solid circles indicate wood $\delta^{15} \mathrm{~N}$, open circles are wood [N], the solid line is 1900 C.E. and the dashed line is the heartwood-sapwood transition.

the same locations, trees generally exhibit the same trends in isotopic composition over time, even species with different growth forms, secondary compounds, wood anatomy, ecology, and function such as conifers and hardwoods (Savard et al., 2009). Quercus seedlings have been shown to have a greater relative preference for $\mathrm{NO}_{3}^{-}$over $\mathrm{NH}_{4}^{+}$when compared to Acer (Templer and Dawson, 2004), which could explain the initially lower $\delta^{15} \mathrm{~N}$ values of Quercus wood. 


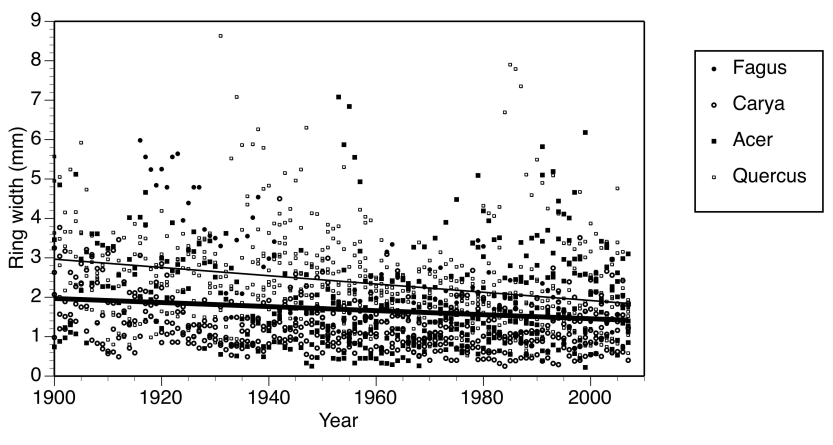

Fig. 5. Increments measured on four hardwood tree species at six sites. Separate linear regression lines are shown for Quercus (light) and the three other hardwood tree species (dark).

If there are differences among trees in their preferences for $\mathrm{NH}_{4}^{+}$and $\mathrm{NO}_{3}^{-}$, then a gradual increase in nitrification would cause $\mathrm{NO}_{3}^{-}$to have a less-depleted $\delta^{15} \mathrm{~N}$ signature (and the signature of Quercus to increase) while the $\delta^{15} \mathrm{~N}$ signature of other species decreased. While we have no direct measurements of nitrification at these sites over time, research from mixed-hardwood forests in southern Indiana suggests that nitrification rates may have been very low - close to zeroat the beginning of the 20th century (Matson and Vitousek, 1981). If the $\mathrm{NO}_{3}^{-}$that Quercus acquired was less depleted and the other species took up more $\mathrm{NO}_{3}^{-}$over time, then this would lead to a gradual enrichment of wood $\delta^{15} \mathrm{~N}$ in Quercus and a depletion of wood $\delta^{15} \mathrm{~N}$ in the other species.

There could be several ultimate drivers of the change in nitrification rate. Predictions from classic $\mathrm{N}$ saturation theory suggest that increased nitrification rates are a consequence of anthropogenic $\mathrm{N}$ deposition (Aber et al., 1989), and increased nitrification rates have indeed been observed at spruce forests in Europe receiving more $\mathrm{N}$ deposition than these North American sites (Corre et al., 2007). Increased nitrification could also be a consequence of forest development, as has been demonstrated on a 100-year chronosequence of upland hardwood forests close to our study sites (Idol et al., 2003). Finally, net nitrification rate is positively correlated with net mineralization rate, and both processes are sensitive to a variety of ecosystem parameters that may have varied over time in these stands, including soil C:N, soil $\mathrm{pH}$, moisture, temperature, and $\mathrm{NH}_{4}^{+}$uptake (Perakis and Sinkhorn 2011; Matson and Vitousek, 1981).

When comparing temporal trends between regions, differences in the absolute amount of $\mathrm{N}$ deposition could be important. A deposition station close to the Indiana forest locations has been indicating approximately $6 \mathrm{~kg} \mathrm{ha}^{-1} \mathrm{y}^{-1}$ of inorganic $\mathrm{N}$ wet deposition over the past decade, and the sites we studied receive approximately 5.76 to $6 \mathrm{~kg} \mathrm{ha}^{-1} \mathrm{yr}^{-1}$ (Fig. 1). In a New Hampshire secondary forest with lower $\mathrm{N}$ deposition rates than the Indiana sites, wood $\delta^{15} \mathrm{~N}$ had consistently declined among five species from 1929 to 2005
C.E., with no indication of wood $\delta^{15} \mathrm{~N}$ significantly increasing for any species (McLauchlan et al., 2007). N deposition rates are approximately $20 \%$ higher in northwest Indiana than they are in New Hampshire, yet there has been no evidence of consistent increases in wood $\delta^{15} \mathrm{~N}$ in the Indiana forests. Application of inorganic $\mathrm{N}$ fertilizer at rates over $10 \mathrm{~kg} \mathrm{ha}^{-1} \mathrm{yr}^{-1}-\mathrm{a}$ level that matches atmospheric deposition rates in some natural systems - tends to increase wood and foliar $\delta^{15} \mathrm{~N}$ (Hietz et al., 2011).

In all, determination of whether stand-level $\delta^{15} \mathrm{~N}$ for these forests is increasing or decreasing will require more precise weighted mass-balance assessments, but there is currently little evidence for consistent trends in stand-level $\mathrm{N}$ availability over time in the Indiana forests. Regardless, the analyses of the wood $\delta^{15} \mathrm{~N}$ in these Indiana forests reveals clear speciesspecific trajectories that may reflect differences in resource partitioning under changing $\mathrm{N}$ cycling. Future research on patterns of dendroisotopic $\delta^{15} \mathrm{~N}$ should include a range of species in a given stand and not assume that patterns for one species are representative of others.

Acknowledgements. We thank the Nature Conservancy, Purdue University, and private landowners for site access. S. and W. McLauchlan provided field support. I. E. Wilson and J. Burniston assisted with sample preparation, and C. Morris provided technical support. We thank T. Ocheltree at the Stable Isotope Mass Spectrometry Laboratory (SIMSL) at Kansas State University for analytical assistance.

Edited by: E. Veldkamp

\section{References}

Aber, J. D., Goodale, C. L., Ollinger, S. V., Smith, M. L., Magill, A. H., Martin, M. E., Hallett, R. A., and Stoddard, J. L.: Is nitrogen deposition altering the nitrogen status of northeastern forests?, Bioscience, 53, 375-389, 2003.

Aber, J. D., Nadelhoffer, K. J., Steudler, P., and Melillo, J. M.: Nitrogen saturation in northern forest ecosystems, Bioscience, 39, 378-386, 1989.

Bao, W., O’Malley, D. M., and Sederoff, R. R.: Wood contains a cell-wall structural protein, P. Natl. A. Sci., 89, 6604-6608, 1992.

Bedard-Haughn, A., van Groenigen, J. W., and van Kessel, C.: Tracing N-15 through landscapes: potential uses and precautions, J. Hydrol., 272, 175-190, 2003.

Bernhardt, E. S., Likens, G. E., Hall, R. O., Buso, D. C., Fisher, S. G., Burton, T. M., Meyer, J. L., McDowell, M. H., Mayer, M. S., Bowden, W. B., Findlay, S. E. G., Macneale, K. H., Stelzer, R. S., and Lowe, W. H.: Can't see the forest for the stream? In-stream processing and terrestrial nitrogen exports, Bioscience, 55, 219-230, 2005.

Bukata, A. R., and Kyser, T. K.: Response of the nitrogen isotopic composition of tree-rings following tree-clearing and land-use change, Environ Sci Technol, 39, 7777-7783, 2005. 
Bukata, A. R. and Kyser, T. K.: Carbon and nitrogen isotope variations in tree-rings as records of perturbations in regional carbon and nitrogen cycles, Environ. Sci. Technol., 41, 1331-1338, 2007.

Corre, M. D., Brumme, R., Veldkamp, E., and Beese, F. O.: Changes in nitrogen cycling and retention processes in soils under spruce forests along a nitrogen enrichment gradient in Germany, Glob. Change Biol., 13, 1509-1527, doi:10.1111/j.13652486.2007.01371.x, 2007.

Cowell, C. M. and Hayes, J. J.: Structure, history and dynamics of a mature oak-beech forest in western Indiana, J. Torrey Bot. Soc., 134, 215-222, 2007.

Cowell, C. M., Hoalst-Pullen, N., and Jackson, M. T.: The limited role of canopy gaps in the successional dynamics of a mature mixed Quercus forest remnant, J. Veg. Sci., 21, 201-212, doi:10.1111/j.1654-1103.2009.01137.x, 2010.

Craine, J. M., Elmore, A. J., Aidar, M. P. M., Bustamante, M., Dawson, T. E., Hobbie, E. A., Kahmen, A., Mack, M. C., McLauchlan, K. K., Michelsen, A., Nardoto, G. B., Pardo, L. H., Peñuelas, J., Reich, P. B., Schuur, E. A. G., Stock, W. D., Templer, P. H., Virginia, R. A., Welker, J. M., and Wright, I. J.: Global patterns of foliar nitrogen isotopes and their relationships with climate, mycorrhizal fungi, foliar nutrient concentrations, and nitrogen availability, New Phytol., 183, 980-992, 2009.

Doucet, A., Savard, M. M., Begin, C., and Smirnoff, A.: Is wood pre-treatment essential for tree-ring nitrogen concentration and isotope analysis? Rapid Comm. Mass. Spec., 25, 469-475, 2011

Elhani, S., Guehl, J. M., Nys, C., Picard, J. F., and Dupouey, J. L.: Impact of fertilization on tree-ring delta N-15 and delta C-13 in beech stands: a retrospective analysis, Tree Physiol., 25, 14371446, 2005.

Galloway, J. N., Dentener, F. J., Capone, D. G., Boyer, E. W., Howarth, R. W., Seitzinger, S. P., Asner, G. P., Cleveland, C. C., Green, P. A., Holland, E. A., Karl, D. M., Michaels, A. F., Porter, J. H., Townsend, A. R., and Vorosmarty, C. J.: Nitrogen cycles: past, present, and future, Biogeochemistry, 70, 153-226, 2004.

Gavin, D. G., Beckage, B., and Osborne, B.: Forest dynamics and the growth decline of red spruce and sugar maple on Bolton Mountain, Vermont: a comparison of modeling methods, Can. J. Forest Res., 38, 2635-2649, doi:10.1139/x08-106, 2008.

Groffman, P. M., Altabet, M. A., Böhlke, J. K., Butterbach-Bahl, K., David, M. B., Firestone, M. K., Giblin, A. E., Kana, T. M., Nielsen, L. P., and Voytek, M. A.: Methods for measuring denitrification: diverse approaches to a difficult problem, Ecol. Appl., 16, 2091-2122, 2006.

Guerrieri, R., Mencuccini, M., Sheppard, L. J., Saurer, M., Perks, M. P., Levy, P., Sutton, M. A., Borghetti, M., and Grace, J.: The legacy of enhanced $\mathrm{N}$ and $\mathrm{S}$ deposition as revealed by the combined analysis of delta $13 \mathrm{C}$, delta $18 \mathrm{O}$ and delta $15 \mathrm{~N}$ in tree rings, Glob. Change Biol., 17, 1946-1962, doi:10.1111/j.13652486.2010.02362.x, 2011.

Handley, L. L. and Raven, J. A.: The use of natural abundance isotopes in plant physiology and ecology, Plant Cell Environ., 15, 965-985, 1992.

Hart, S. C. and Classen, A. T.: Potential for assessing long-term dynamics in soil nitrogen availability from variations in delta $\mathrm{N}$ 15 of tree rings, Isot. Environ. Healt. S., 39, 15-28, 2003.

Hietz, P., Dunisch, O., and Wanek, W.: Long-term trends in nitro- gen isotope composition and nitrogen concentration in Brazilian rainforest trees suggest changes in nitrogen cycle, Environ. Sci. Tech., 44, 1191-1196, 2010.

Hietz, P., Turner, B. L., Wanek, W., Richter, A., Nock, C. A., and Wright, S. J.: Long-term change in the nitrogen cycle of tropical forests, Science, 334, 664-666, 2011.

Hobbie, E. A. and Colpaert, J. V.: Nitrogen availability and colonization by mycorrhizal fungi correlate with nitrogen isotope patterns in plants, New Phytol., 157, 115-126, 2003.

Högberg, P.: Tansley review No 95 - N-15 natural abundance in soil-plant systems, New Phytol., 137, 179-203, 1997.

Högberg, P., Johannisson, C., Yarwood, S., Callesen, I., Nasholm, T., Myrold, D. D., and Hogberg, M. N.: Recovery of ectomycorrhiza after "nitrogen saturation" of a conifer forest, New Phytol., 189, 515-525, doi:10.1111/j.1469-8137.2010.03485.x, 2011.

Houlton, B. Z., Sigman, D. M., and Hedin, L. O.: Isotopic evidence for large gaseous nitrogen losses from tropical rainforests, P. Natl. Acad. Sci. USA, 103, 8745-8750, 2006.

Houlton, B. Z. and Bai, E.: Imprint of denitrifying bacteria on the global terrestrial biosphere, P. Natl. Acad. Sci. USA, 106, $21713-$ 21716, doi:10.1073/pnas.0912111106, 2009.

Idol, T. W., Pope, P. E., and Ponder, F.: $\mathrm{N}$ mineralization, nitrification, and $\mathrm{N}$ uptake across a 100-year chronosequence of upland hardwood forests, For. Ecol. Manag., 176, 509-518, doi:10.1016/s0378-1127(02)00232-3, 2003.

Johnson, D. W.: Progressive N limitation in forests: Review and implications for long-term responses to elevated $\mathrm{CO}_{2}$, Ecology, 87, 64-75, 2006.

Kahmen, A., Wanek, W., and Buchmann, N.: Foliar delta N-15 values characterize soil $\mathrm{N}$ cycling and reflect nitrate or ammonium preference of plants along a temperate grassland gradient, Oecologia, 156, 861-870, 2008.

Kareiva, P., Watts, S., McDonald, R., and Boucher, T.: Domesticated nature: Shaping landscapes and ecosystems for human welfare, Science, 316, 1866-1869, 2007.

Luo, Y., Su, B., Currie, W. S., Dukes, J. S., Finzi, A., Hartwig, U., Hungate, B., McMurtrie, R. E., Oren, R., Parton, W. J., Pataki, D. E., Shaw, M. R., Zak, D. R., and Field, C. B.: Progressive nitrogen limitation of ecosystem responses to rising atmospheric carbon dioxide, Bioscience, 54, 731-739, 2004.

Matson, P. A. and Vitousek, P. M.: Nitrogen mineralization and nitrification potentials following clearcutting in the Hoosier National Forest, Indiana, For. Sci., 27, 781-791, 1981.

McCarroll, D. and Loader, N. J.: Stable isotopes in tree rings, Quaternary Science Reviews, 23, 771-801, 2004.

McLauchlan, K. K., Craine, J. M., Oswald, W. W., Leavitt, P. R., and Likens, G. E.: Changes in nitrogen cycling during the past century in a northern hardwood forest, P. Natl. A. Sci., 104, 7466-7470, 2007.

Menyailo, O. V. and Hungate, B. A.: Stable isotope discrimination during soil denitrification: Production and consumption of nitrous oxide, Global Biogeochem. Cy., 20, 3025-3035, 2006.

Merrill, W. and Cowling, E. B.: Role of nitrogen in wood deterioration - amounts and distribution of nitrogen in tree stems, Can. J. Bot., 44, 1555-1580, 1966.

Olson, D. M., Dinerstein, E., Wikramanayake, E. D., Burgess, N. D., Powell, G. V. N., Underwood, E. C., D’ Amico, J. A., Itoua, I., Strand, H. E., Morrison, J. C., Loucks, C. J., Allnutt, T. F., Ricketts, T. H., Kura, Y., Lamoreux, J. F., Wettengel, W. W., Hedao, 
P., and Kassem, K. R.: Terrestrial ecoregions of the worlds: A new map of life on Earth, Bioscience, 51, 933-938, 2001.

Pardo, L. H., Hemond, H. F., Montoya, J. P., Fahey, T. J., and Siccama, T. G.: Response of the natural abundance of $\mathrm{N}-15$ in forest soils and foliage to high nitrate loss following clear-cutting, Can. J. For. Res., 32, 1126-1136, 2002.

Pardo, L. H., Templer, P. H., Goodale, C. L., Duke, S., Groffman, P. M., Adams, M. B., Boeckx, P., Boggs, J., Campbell, J., Colman, B., Compton, J., Emmett, B., Gundersen, P., Kjonaas, J., Lovett, G., Mack, M., Magill, A., Mbila, M., Mitchell, M. J., McGee, G., McNulty, S., Nadelhoffer, K., Ollinger, S., Ross, D., Rueth, H., Rustad, L., Schaberg, P., Schiff, S., Schleppi, P., Spoelstra, J., and Wessel, W.: Regional assessment of N saturation using foliar and root delta N-15, Biogeochemistry, 80, 143-171, 2006.

Pepper, D. A., Eliasson, P. E., McMurtrie, R. E., Corbeels, M., Agren, G. I., Stromgren, M., and Linder, S.: Simulated mechanisms of soil $\mathrm{N}$ feedback on the forest $\mathrm{CO}_{2}$ response, Glob. Change Biol., 13, 1265-1281, 2007.

Perakis, S. S. and Sinkhorn, E. R.: Biogeochemistry of a temperate forest nitrogen gradient, Ecology, 92, 1481-1491, 2011.

Saurer, M., Cherubini, P., Ammann, M., De Cinti, B., and Siegwolf, R.: First detection of nitrogen from $\mathrm{NO}_{\mathrm{x}}$ in tree rings: a N-15/N-14 study near a motorway, Atmos. Environ., 38, 27792787, doi:10.1016/j.atmosenv.2004.02.037, 2004.
Savard, M. M., Begin, C., Smirnoff, A., Marion, J., and RiouxPaquette, E.: Tree-ring nitrogen isotopes reflect anthropogenic NOx emissions and climatic effects, Environ. Sci. Tech., 43, 604-609, doi:10.1021/es802437k, 2009.

Savard, M. M.: Tree-ring stable isotopes and historical perspectives on pollution - An overview, Environ. Pollut., 158, 2007-2013, doi:10.1016/j.envpol.2009.11.031, 2010.

Schimel, J. P. and Bennett, J.: Nitrogen mineralization: Challenges of a changing paradigm, Ecology, 85, 591-602, 2004.

Showalter, A. M.: Structure and function of plant cell wall proteins, Plant. Cell., 5, 9-23, 1993.

Stoddard, J. L., Jeffries, D. S., Lukewille, A., Clair, T. A., Dillon, P. J., Driscoll, C. T., Forsius, M., Johannessen, M., Kahl, J. S., Kellogg, J. H., Kemp, A., Mannio, J., Monteith, D. T., Murdoch, P. S., Patrick, S., Rebsdorf, A., Skjelkvale, B. L., Stainton, M. P., Traaen, T., van Dam, H., Webster, K. E., Wieting, J., and Wilander, A.: Regional trends in aquatic recovery from acidification in North America and Europe, Nature, 401, 575-578, 1999.

Templer, P. H. and Dawson, T. E.: Nitrogen uptake by four tree species of the Catskill Mountains, New York: Implications for forest N dynamics, Plant. Soil., 262, 251-261, 2004. 